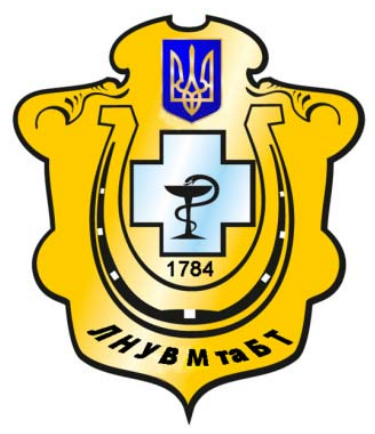

Науковий вісник Львівського національного університету ветеринарної медицини та біотехнологій імені С.3. Гжицького

Scientific Messenger of Lviv National University of Veterinary Medicine and Biotechnologies named after S.Z. Gzhytskyj

doi:10.15421/nvlvet7106

ISSN 2413-5550 print

ISSN 2518-1327 online

$\underline{\text { http://nvlvet.com.ua/ }}$

УДК 619:615.9:636.085

\title{
Ефективність добавки «Силімаск» за експериментального токсикозу у щурів
}

\author{
О.Ю. Журавльов, В.М. Гунчак \\ bara2002@gmail.com
}

\begin{abstract}
Львівський національний університет ветеринарної медицини та біотехнологій ім. С. З. Гжиџького, вул. Пекарська, 50, м. Львів, 79010, Україна
\end{abstract}

За умов експериментального хронічного отруєння тетрахлорметаном у щурів виявлено ознаки пригнічення, слабку реакиію на зовнішні подразники, пригнічення апетиту. У крові піддослідних тварин встановлено зниження загальної кількості еритроцитів та вмісту гемоглобіну. На тлі лейкоцитозу характерною ознакою була еозинофілія та нейтрофілія. Зниження функціонального стану печінки підтверджено пригніченням ії протеїнсинтезувальної та дезінтоксикаційної функцій $i$ достовірним зростанням активності трансаміназ та лужної фосфатази. Застосування з лікувальною метою біодобавки «Силімаск» сприяло відновленню функціонального стану організму піддослідних щурів. Так, на 30 добу досліду у тварин встановлено збільшення у крові кількості еритроцитів та вмісту гемоглобіну. Присутність у складі БАД розмелених плодів розторопші плямистої, бджолиного пилку та аскорбінової кислоти забезпечило ефективну протизапальну, гепатопротекторну та антиоксидантну дії за штучно створеного гепатиту. У сироватиі крові шурів за використання біологічноактивної добавки достовірно зростав рівень загального протеїну, в тому числі альбумінів, знижувалась активність аспартатамінотрансферази, аланінамінотрансферази та лужної фосфатази. Зростання активності у крові каталази та пригнічення процесів перекисного окиснення ліпідів, що підтверджується зниженням у крові вторинних та кінцевих продуктів окиснення за впливу "Силімаску» є результатом активачії препаратом ензимної ланки антиоксидантної системи. Застосування з лікувальною метою препарату порівняння «Гепатон», щзо теж містить у своєму складі плоди розторопші плялистої викликає позитивний ефект за хронічного гепатиту у піддослідних щурів. Однак, цей вплив у циифрових вимірах був менш виражений а період повного відновлення функиіонального стану організму тварин більш довгим.

Ключові слова: хронічний токсикоз, «Силімаск», «Гепатон», білі щурі, тетрахлорметан, кров.

\section{Эффективность добавки «Силимаск» при экспериментальном токсикозе у крыс}

\author{
О.Ю. Журавлев, В.М. Гунчак \\ bara2002@gmail.com
}

\begin{abstract}
Львовский национальный университет ветеринарной медицины и биотехнологий им. С.З. Гжицкого, ул. Пекарская, 50, м. Львов, 79010, Украина
\end{abstract}

В условиях экспериментального хронического отравления тетрахлорметаном у крыс обнаружены признаки угнетения, слабую реакиию на внешние раздражители, подавление аппетита. В крови подопытных животных установлено снижение общего количества эритроцитов и содержания гемоглобина. На фоне лейкоцитоза характерным признаком была эозинофилия и нейтрофилия. Снижение функичинального состояния печени подтверждено угнетением ее протеинсинтетической и дезинтоксикационной функиий и достоверным ростом активности трансаминаз и щелочной фосфатазы. Применение с лечебной иелью биодобавки «Силимаск» способствовало восстановлению функиионального состояния организма подопытных крыс. Так, на тридиатый день опыта у жсивотных установлено увеличение в крови количества эритроцитов и содержания гемоглобина. Присутствие в составе БАД размолотых плодов расторопши пятнистой, пыльиьы и аскорби-

Citation:

Zhuravlov, O., Hunchak, V. (2016). The effectiveness of additives «Sylimask» of experimental toxicity in rats. Scientific Messenger LNUVMBT named after S.Z. Gzhytskyj, 18, 3(71), 25-29. 
новой кислоты обеспечило эффективное противовоспалительное, гепатопротекторное и антиоксидантное действия при искусственно созданном гепатите. В сыворотке крови крыс при использовании биологически активной добавки достоверно возрастал уровень общего белка, в том числе альбумина, снижалась активность аспартатаминотрансферазьл, аланинаминотрансферазы и щелочной фосфатазы. Рост активности в крови каталазы и угнетение процессов перекисного окисления липидов, что подтверждается снижением в крови вторичных и конечных продуктов окисления, при воздействии «Силимаску», является результатом активации препаратом энзимного звена антиоксидантной системыл. Применение с лечебной целью препарата сравнения "Гепатон», что тоже содержит в своем составе плоды расторопии пятнистой, вызывает положительный эффект за хронического гепатита у подопытных крыс. Однако, это влияние в циффровых измерениях было менее выражено а период полного восстановления функционального состояния организма животных более длиннымм.

Ключевые слова: хронический токсикоз, «Силимаск», «Гепатон», белье крысы, тетрахлорметан, кровь

\title{
The effectiveness of additives «Sylimask» of experimental toxicity in rats
}

\author{
O. Zhuravlov, V. Hunchak \\ bara2002@gmail.com

\begin{abstract}
Lviv National University of Veterinary Medicine and Biotechnologies named after S.Z. Gzhytskyj, Pekarska Str., 50, Lviv, 79010, Ukraine
\end{abstract}

\begin{abstract}
Chronic experimental poisoning of rats by carbon tetrachloride is accompanied by depression, reduced appetite, weak response to external stimuli. It has been shown a reduction of erythrocytes and hemoglobin in the blood of experimental animals. Eosinophilia and neutrophilia also was observed in these rats. A decrease of functional state of liver is by inhibition of protein synthesis and detoxification functions and significant increased of activity of transaminases and alkaline phosphatase. The use of supplements for medicinal purposes «Sylimask» helped restore the functional state of the experimental rats. On the 30 day experiment, the animals found in the blood increase the number of erythrocytes and hemoglobin. The presence in the composition of dietary supplements milled fruits of milk thistle, bee pollen and ascorbic acid provided an effective anti-inflammatory, antioxidant and hepatoprotective action on experimental hepatitis. Serum of rats by using biologically active supplements significantly increased serum total protein, including albumin, decreased activity of aspartate aminotransferase, alanine aminotransferase, and alkaline phosphatase. The increase in blood catalase activity and inhibition of lipid peroxidation, as evidenced by a decrease in blood secondary and end products of oxidation by exposure «Sylimasku» is the result of activation of the drug enzymatic antioxidant system level. The use of for cure a preparation of comparison "Hepaton», which also contains in its composition the fruits milk thistle is a positive effect on chronic hepatitis $B$ in the experimental rats. However, the impact of digital measurements was a less pronounced and the period of a full restoration of the functional state of animals longer.
\end{abstract}

Key words: Chronic toxicosis, «Sylimask», «Hepaton», white rats, carbon tetrachloride, blood.

\section{Вступ}

Відомо, що надходження в організм тварин чужерідних речовин різко пригнічує функціональний стан їх печінки, проявляє негативний вплив на імунну та антиоксидантну системи (Skakun and Vysockij, 1984; Belenichev, 2002; Algasonmi, 2010). Методи лікування патології печінки у тварин розроблені недостатньо. Більшість із наявних засобів терапії лише частково відновлюють імунний стан. Більш перспективними $є$ рослинні препарати, оскільки вони спричиняють «м'яку» біологічну дію, яка не супроводжується різкими змінами гомеостазу, що притаманно для більшості хіміотерапевтичних фармакологічних препаратів (Skakun et al., 1995; Gordienko, 2000).

Цікавим, з нашої точки зору, було вивчення впливу новоствореної біодобавки «Силімаск», на основі розмелених плодів розторопші за експериментально створеної патології печінки.

Загальновідомо, що розторопша плямиста має сильно виражені гепатопротекторні та антиоксидантні властивості. За рахунок наявності в ній флаволігнану «силімарину» вона підвищує білоксинтезувальну, дезінтоксикаційну і жовчогінну функції печінки, що особливо важливо за екзо- і ендотоксикозів у тварин (Valenzuela et al., 1985; Vengerovskij, 1987; Kurkin, 2003).
Метою даної роботи було встановити ступінь інтоксикації білих щурів за експериментально створеної патології та вивчити вплив новоствореної комплексної біодобавки на відновлення функціонального стану печінки та кровотворну і антиоксидантну системи лабораторних тварин.

\section{Матеріал і методи досліджень}

Гепатопротекторну та антиоксидантну дії БАД «Силімаск» з'ясовували в умовах модельного досліду на 24 білих щурах, масою 170 - 220 г. Тварин утримували в умовах віварію зі сталою температурою та вологістю, на стандартному раціоні. Адаптація до умов проведення досліду проводилась впродовж 10 12 діб. Відхилень у поведінкових реакціях лабораторних тварин не спостерігалось.

Експериментальну хронічну інтоксикацію у тварин проводили за методикою, описаною І.В. Мацьопа у нашій модифікації (Мас'ора et al., 2012) шляхом дворазового (через 48 год) внутрішлункового введення тетрахлоретану у дозі 0,1 мл на 100 г маси тіла щура у вигляді $50 \%$ олійного розчину.

3 метою вивчення лікувальної ефективності новоствореної біодобавки за експериментального токсикозу білим щурам впродовж 30 діб згодовували «Силімаск» у дозі 0,1 г на 100 г м.т. разом із кормом $\left(\mathrm{D}_{1}\right)$. 
Для порівняння його дії ще одній дослідній групі $\left(\mathrm{D}_{2}\right)$ задавали гепатопротекторний комплекс «Гепатон», до складу якого теж входили плоди розторопші плямистої. За контроль служили інтактні тварини $\left(\mathrm{K}_{1}\right)$ та хворі, що не піддавалися лікуванню $\left(\mathrm{K}_{2}\right)$.

Кров для досліджень у білих щурів брали після їх декапітації за легкого ефірного наркозу. У крові визначали кількість еритроцитів, лейкоцитів, вміст гемоглобіну, індекси червоної крові, лейкограму. У сироватці крові досліджували концентрацію загального протеїну і його фракційний склад, активність гепатозалежних ферментів (АлАТ, АсАТ і ЛФ). Антиоксидантний статус встановлювали за оцінкою активності ферменту каталази у сироватці крові та концентрацією ТБК - активних продуктів ы дієнових кон'югатів (Vlizlo et al., 2012).

\section{Результати та їх обговорення}

У результаті проведених експериментальних досліджень нами було з'ясовано, що у лабораторних тварин за штучно викликаного токсикозу (група К $\mathrm{K}_{2}$ ) зазнає відчутних змін картина крові (табл.1). Так, у хворих щурів знижується, порівняно 3 показниками інтактних тварин, кількість еритроцитів та вміст гемоглобіну, відповідно, на 31,3\% і 11,8\%.

При цьому, відзначено зростання колірного показника до 1,17 та зниження гематокритної величини. На порушення процесів кровотворення за токсикозу вказують також зміни індексів крові. За збільшення середнього об'єму еритроцитів і вмісту гемоглобіну в еритроциті відзначена тенденція до зменшення середньої концентрації гемоглобіну в еритроциті. Наявні коливання є реакцією на дію екзотоксину і на початкових етапах розвитку патології, ймовірно, носять компенсаторний характер.

Зростання числа лейкоцитів у крові щурів після введення їм тетрахлорметану є результатом розвитку в організмі запальних процесів (табл. 2).

Кількість лейкоцитів у щурів 2-ї групи $\left(\mathrm{K}_{2}\right)$ за експериментального токсикозу перевищувала даний показник у групі клінічно здорових тварин $\left(\mathrm{K}_{1}\right)$ на $33,4 \%$. За аналізом лейкограми встановлено відчутнє зменшення у білій крові лімфоцитів (на 23,9\%) на тлі еозинофілії та нейтрофілії, що супроводжує перебіг патологічного процесу і є результатом впливу інтоксикації на організм.

Таблиця 1

Вплив препаратів «Силімаск» та «Гепатон» на морфологічні показники крові білих щурів за експериментального токсикозу, $(\mathrm{M} \pm \mathrm{m} ; \mathrm{n}=6)$

\begin{tabular}{|l|c|c|c|c|}
\hline \multirow{2}{*}{\multicolumn{1}{|c|}{ Показники }} & \multicolumn{4}{c|}{ Групи тварин } \\
\cline { 2 - 5 } & $\mathrm{I}\left(\mathrm{K}_{1}\right)$ & $\mathrm{II}\left(\mathrm{K}_{2}\right)$ & III $\left(Д_{1}\right)$ & IV $\left(Д_{2}\right)$ \\
\hline Еритроцити, Т/л & $8,82 \pm 0,34$ & $6,72 \pm 0,62$ & $9,12 \pm 0,42$ & $8,20 \pm 0,55$ \\
\hline Гемоглобін, г/л & $115,4 \pm 8,2$ & $103,2 \pm 6,18$ & $120,2 \pm 5,7^{* *}$ & $115,3 \pm 6,12$ \\
\hline Гематокрит, л/л & $30,92 \pm 3,86$ & $29,46 \pm 1,41$ & $32,40 \pm 4,16$ & $30,16 \pm 4,18$ \\
\hline Колірний показник & $0,99 \pm 0,08$ & $1,17 \pm 0,06$ & $1,01 \pm 0,08$ & $1,07 \pm 0,09$ \\
\hline МСV (СОЕ), фл & $35,05 \pm 2,40$ & $43,83 \pm 3,56$ & $35,52 \pm 4,16^{* *}$ & $36,78 \pm 3,84^{* * *}$ \\
\hline МСН (ВГЕ), флмоль & $0,82 \pm 0,06$ & $0,97 \pm 0,06$ & $0,83 \pm 0,07^{*}$ & $0,88 \pm 0,04$ \\
\hline МСНС (СКГЕ), кмоль/л & $23,16 \pm 1,14$ & $21,74 \pm 2,60$ & $23,02 \pm 2,88^{* *}$ & $23,72 \pm 3,12^{* *}$ \\
\hline
\end{tabular}

Примітка: $* \mathrm{p}<0,05 ; * *-\mathrm{p}<0,01 ; * * *-\mathrm{p}<0,001$, порівняно 3 показниками контролю. $\left(\mathrm{K}_{2}\right)$ - хворі, не ліковані тварини.

Таблиця 2

Лейкограма крові білих щурів за експериментального токсикозу і лікування БАД «Силімаск» та «Гепатоном», $(\mathrm{M} \pm \mathrm{m} ; \mathrm{n}=\mathbf{6})$

\begin{tabular}{|l|c|c|c|c|}
\hline \multirow{2}{*}{ Показники } & \multicolumn{4}{c|}{ Групи тварин } \\
\cline { 2 - 5 } & $\mathrm{I}\left(\mathrm{K}_{1}\right)$ & $\mathrm{II}\left(\mathrm{K}_{2}\right)$ & $\mathrm{III}\left(Д_{1}\right)$ & IV $\left(Д_{2}\right)$ \\
\hline Лейкоцити, Г/л & $6,76 \pm 0,66$ & $9,02 \pm 0,84$ & $6,94 \pm 0,66$ & $6,98 \pm 0,94$ \\
\hline Моноцити, \% & $0,84 \pm 0,08$ & $1,12 \pm 0,24$ & $1,02 \pm 0,06$ & $0,96 \pm 0,12$ \\
\hline Лімфоцити, \% & $60,6 \pm 6,26$ & $48,2 \pm 5,14$ & $56,4 \pm 4,18^{* * *}$ & $50,8 \pm 6,12^{* *}$ \\
\hline Базофіли, \% & $1,46 \pm 0,12$ & $1,88 \pm 0,2$ & $1,62 \pm 0,32$ & $1,72 \pm 0,18$ \\
\hline Еозинофіли, \% & $3,24 \pm 0,24$ & $5,08 \pm 0,34$ & $4,46 \pm 0,42$ & $4,56 \pm 0,38$ \\
\hline Паличко-ядерні нейтрофіли, \% & $6,12 \pm 0,72$ & $8,16 \pm 0,70$ & $7,18 \pm 0,54$ & $6,92 \pm 0,62$ \\
\hline Сегментно-ядерні нейтрофіли, \% & $27,74 \pm 1,16$ & $35,56 \pm 2,04$ & $29,32 \pm 1,96^{*}$ & $35,04 \pm 2,32$ \\
\hline
\end{tabular}

Використання $з$ лікувальною метою, за експериментального токсикозу, БАД «Силімаск» мало позитивний вплив на відновлення процесів кровотворення (табл. 2). Згодовування білим щурам впродовж 30 діб БАД сприяло збільшенню у крові еритроцитів та гемоглобіну, по відношенню до показника крові хворих тварин, що не отримували БАД, на, відповідно, 35,7\% і 16,0\%. За нормалізації кількості еритроцитів та гемоглобіну у дослідних щурів індекси крові набули показників, близьких до тварин першої контрольної групи $\left(\mathrm{K}_{1}\right)$. Присутність у складі БАД розмелених плодів розторопші плямистої, бджолиного пилку та окремих антиоксидантів забезпечило ефективну протизапальну, гепатопротекторну та антиоксидантну дії за гепатиту. Це підтверджено зниженням у крові кількості лейкоцитів із 9,02 $\pm 0,84$ до 6,94 $\pm 0,66$ Г/л, або на $30 \%$. На позитивний перебіг патологічного процесу вказує також тенденція до зниження нейтрофілів, i особливо сегментно-ядерних, вірогідне зниження числа яких відбулося на 17,7\%. Ефективний процес відновлення гомеостазу у піддослідних тварин підт- 
верджено також зростанням у крові лімфоцитів на $15,3 \%$.

Згодовування білим щурам за штучно створеної патології препарату порівняння «Гепатон» також викликало позитивні зміни в організмі тварин. Однак, цей вплив у цифрових вимірах був менш вираженим. Так, число еритроцитів та вміст гемоглобіну у крові знаходилися у межах показників інтактних щурів, однак за дії гепатону відсоток сегментно-ядерних лейкоцитів ще був близьким до показника хворих тварин.

За експериментально створеної патології, зокрема хронічного гепатиту, викликаного тетрахлорметаном у білих щурів знизився функціональний стан печінки (табл. 3).

За аналізом отриманих даних з'ясовано, що сироватці хворих тварин відзначена тенденція до зниження концентрації загального протеїну, хоч цей показник i не виходить за межі фізіологічних для цього виду тварин.

Ймовірне пригнічення протеїнсинтезувальної функції печінки у тварин призвело до зменшення у сироватці крові відсотка альбумінів та незначного зростання глобулінової фракції і зокрема $\gamma$-глобулінів.

Табличя 3

\begin{tabular}{|c|c|c|c|c|}
\hline \multirow[t]{2}{*}{ Показники } & \multicolumn{4}{|c|}{ Групи тварин } \\
\hline & $\mathrm{I}\left(\mathrm{K}_{1}\right)$ & II $\left(\mathrm{K}_{2}\right)$ & III $\left(Д_{1}\right)$ & IV $\left(Д_{2}\right)$ \\
\hline Протеїн загальний, г/л & $62,60 \pm 4,22$ & $60,22 \pm 7,12$ & $64,24 \pm 6,92 * * *$ & $62,12 \pm 5,16^{* *}$ \\
\hline Альбуміни, г/л & $24,05 \pm 2,18$ & $20,26 \pm 3,14$ & $25,06 \pm 4,04 * *$ & $23,18 \pm 3,82^{*}$ \\
\hline Глобуліни, г/л & $38,55 \pm 3,88$ & $39,96 \pm 5,08$ & $39,18 \pm 6,22$ & $38,94 \pm 5,84$ \\
\hline$\beta$-глобуліни, г/л & $10,84 \pm 0,66$ & $9,44 \pm 0,82$ & $10,12 \pm 0,70$ & $9,96 \pm 0,54$ \\
\hline$\gamma$-глобуліни, г/л & $16,42 \pm 0,82$ & $20,36 \pm 0,66$ & $18,38 \pm 0,82$ & $18,43 \pm 0,76$ \\
\hline 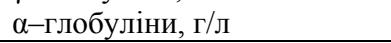 & $11,29 \pm 0,36$ & $10,16 \pm 0,24$ & $10,68 \pm 0,44$ & $10,55 \pm 0,52$ \\
\hline Коефіціет А/Г & $0,62 \pm 0,03$ & $0,50 \pm 0,025$ & $0,64 \pm 0,033^{*}$ & $0,60 \pm 0,042$ \\
\hline АлАТ, од/л & $37,62 \pm 2,16$ & $49,16 \pm 4,84 * *$ & $38,22 \pm 5,18$ & $41,48 \pm 4,86$ \\
\hline АсАТ, од/л & $48,78 \pm 4,96$ & $54,62 \pm 6,18 * *$ & $50,24 \pm 5,50$ & $52,76 \pm 6,92$ \\
\hline Лужна фосфатаза, мккат/л & $1,54 \pm 0,22$ & $2,64 \pm 0,32 * * *$ & $1,62 \pm 0,20$ & $1,64 \pm 0,16$ \\
\hline Каталаза, мкат/л & $4,28 \pm 0,36$ & $2,22 \pm 0,32$ & $4,90 \pm 0,54 * * *$ & $4,46 \pm 0,50 * * *$ \\
\hline ТБК-акт.продукти, кмоль/л & $4,48 \pm 0,24$ & $6,60 \pm 0,46$ & $4,92 \pm 0,52 *$ & $5,16 \pm 0,41$ \\
\hline Дієнові кон'югати, кмоль/л & $0,029 \pm 0,003$ & $0,046 \pm 0,003$ & $0,032 \pm 0,004^{*}$ & $0,036 \pm 0,004$ \\
\hline
\end{tabular}

На наявність запальних процесів з елементами деструктивних змін у структурі гепатоцитів вказувало зростання активності печінковозалежних ферментів, i зокрема амінотрансфераз та лужної фосфатази. Так, активність АлАТ і АсАТ у сироватці крові дослідної групи білих щурів (за токсикозу без згодовування БАД) перевищувала показники інтактних щурів, відповідно, на 30,7\% і 12,0\%. Крім того, на понад 70\% $(\mathrm{p}<0,001)$ зростала активність лужної фосфатази.

Відновленню функціонального стану печінки сприяло згодовування хворим тваринам досліджуваної нами добавки «Силімаск», що проявляла свою позитивну гепатопротекторну дію за рахунок присутності в ній флаволігнанів розторопші плямистої та біологічно-активних речовин бджолиного пилку i антиоксидантів (аскорбінова кислота і метіфен). 30-и добове використання $з$ лікувальною метою БАД «Силімаск» сприяло вірогідному зростанню у сироватці крові щурів дослідної групи рівня загального протеїну на $6,7 \%$. За використання хворим тваринам гепатону нами було теж відзначено збільшення концентрації досліджуваного показника, який наближався до аналогічного у групі клінічно здорових щурів, а у порівнянні до показника хворих тварин, був вищим на 3,2\%. Активізація протеїнсинтезувальної функції печінки за згодовування піддослідним тваринам БАД «Силімаск» відбувалася через посилене утворення альбумінів. Так, вміст цієї протеїнової фракції у сироватці крові білих щурів дослідних груп Д 1 Д 2 зріс, відповідно, на 23,7\% і 14,4\% (p < 0,001). Суттєвих змін у концентрації протеїнів глобулінової фракції, за згодовування БАД не проходило, хоч нами відзначено тенденцію до деякого зниження рівня $\gamma$-глобулінів.

На тлі хронічного токсикозу у щурів функціональний стан їхньої печінки дещо пригнічується, однак застосування БАД і гепатопротекторного комплексу сприяє його відновленню.

Підтвердженням цьому є також аналіз зміни активності АлАТ і АсAТ у сироватці крові. За згодовування піддослідним тваринам БАД «Силімаск» активність АлАТ у сироватці крові щурів, порівняно до аналогічного показника групи $\mathrm{K}_{2}$ вірогідно знижується на $28,6 \%(\mathrm{p}<0,001) .30$ добове згодовування тваринам іншого гепатопротекторного комплексу «Гепатон» теж мало позитивний вплив на відновлення печінки і забезпечувало зменшення активності АлАТ на $18,5 \%(\mathrm{p}<0,001)$. Активність ферменту АсАТ, у випадках із двома досліджуваними добавками знижувалась, хоч кращий результат отримано за згодовування БАД «Силімаск».

Пригнічення стану печінки за хронічної інтоксикації відбувалося також через розвиток у дослідної групи білих щурів оксидаційного стресу. Підтвердженням цього були встановлені нами зміни у системі антиоксидантного захисту. Так, у сироватці крові тварин, що піддавалися експериментальній інтоксикації рівень ТБК - активних продуктів і дієнових кон'югатів зростав на 17,3\% і 58,7\% (табл. 3). При цьому, активність ферменту каталази була нижчою за показник інтактних щурів на 58,6\% (p < 0,001).

У процесі проведених досліджень щодо впливу БАД «Силімаск» нами було встановлено, що 30 добове iii згодовування білим щурам за експериментально- 
го токсикозу сприяє активації ензимної ланки антиоксидантної системи, на що вказує зростання активності у сироватці крові каталази у понад 2 рази та пригнічення процесів пероксидного окиснення ліпідів, що підтверджується зниженням у крові вторинних та кінцевих продуктів окиснення (рівень ТБК - активних продуктів вірогідно знизився на $34,1 \%$, а дієнових кон'югатів на 43,8\% (p<0,05).

\section{Висновки}

30 добове введення біодобавки «Силімаск» білим щурам за експериментального отруєння сприяє відновленню в них функціонального стану печінки та показників, що характеризують процес кровотворення та антиоксидантний захист.

Перспективи подальших досліджень. Ефективність біологічно-активної добавки «Силімаск» буде в подальшому вивчено на домашніх тварина за патології печінки.

\section{Бібліографічні посилання}

Skakun, N.P., Vysockij, I.Ju. (1984). Jeffektivnost' vitamina E i selenita natrija pri porazhenii pecheni chetyrehhloristym uglerodom $\mathrm{v}$ zavisimosti ot sezona goda. Vopr. pitanija. 6, 50-54 (in Russian).

Algasonmi, S. (2010). Carbon Tetracloridein-duced Hepathotoxiciti: Protective Effect of Rocket Eruca Sative L. in Rats. American Journal of Chinese Medicine. 38, 75-88.

Belenichev, I.F. (2002). Antioksidantnaja sistema zashhity organizma. Sovr.probl. toksikologii. 3, 24-31 (in Russian).
Gordienko, A.D. (2000). Vlijanie rastitel'nyh gepatoprotektornyh substancij na membranometalicheskuju aktivnost' organell kletok pecheni pri jeksperimental'nyh toksicheskih gepatitah. Zhurn. AMN Ukrainy. 6(3), 587-591 (in Russian).

Skakun, N.P., Shman'ko, V.V., Ohrimovich, L.M. (1995). Klinicheskaja farmakologija gepatoprotektorov: Rukovodstvo. Ternopol': Zbruch (in Russian).

Vengerovskij, A.I. (1987). Gepatozashhitnoe dejstvie silibinina pri jeksperimental'noj intoksikacii chetirehloristim uglerodom. Farmakologija i toksikologija. 50(5), 67-69 (in Russian).

Valenzuela, A., Lagos, C., Schmidt, K., Videla, L. (1985). Silymarin protection against hepatic lipid peroxudation induced by acute ethanol interactions in the rat. Biochem. Pharmacol. 134, 2209-2212.

Kurkin, V.A. (2003). Antioksidantnye svojstva flavolignanov plodov Silibum marianum. Rastitel'nye resursy. 1, 89-94 (in Russian).

Mac'opa, I.V., Grygor'jev, N.P., Velyka, A.Ja. (2012). Koreljacijnyj zv'jazok pokaznykiv vil'no radykal'nogo okysnennja i antyoksydantnoi' systemy $\mathrm{v}$ nyrkah shhuriv pry intoksykacii' tetrahloretanom. Ukrai'ns'kyj zhurnal klinichnoi' ta laboratornoi' medycyny, 7(4), 78-82 (in Ukrainian).

Vlizlo, V.V., Fedoruk, R.S., Ratych, I.B. (2012). Laboratorni metody doslidzhen $u$ biolohiyi, tvarynnytstvi ta veterynarniy medytsyni. [Laboratory methods of investigation in biology, stock-breeding and veterinary]: Dovidnyk - Reference book (in Ukrainian).

Стаття надійшла до редакиії 5.10.2016 